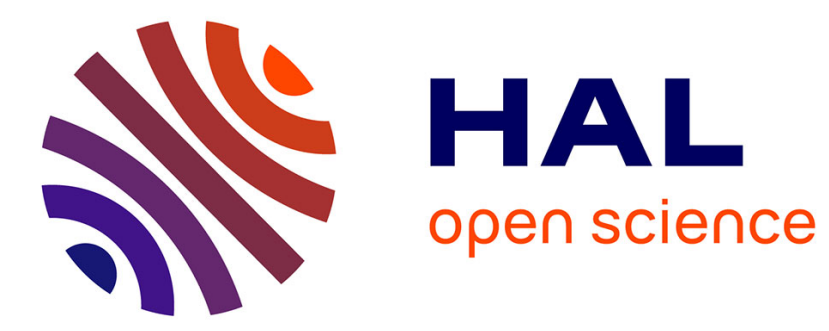

\title{
Characteristics of an urban fish assemblage: distribution of fish associated with coastal marinas
}

B.G. Clynick

\section{To cite this version:}

B.G. Clynick. Characteristics of an urban fish assemblage: distribution of fish associated with coastal marinas. Marine Environmental Research, 2007, 65 (1), pp.18. 10.1016/j.marenvres.2007.07.005 . hal-00562989

\section{HAL Id: hal-00562989 \\ https://hal.science/hal-00562989}

Submitted on 4 Feb 2011

HAL is a multi-disciplinary open access archive for the deposit and dissemination of scientific research documents, whether they are published or not. The documents may come from teaching and research institutions in France or abroad, or from public or private research centers.
L'archive ouverte pluridisciplinaire HAL, est destinée au dépôt et à la diffusion de documents scientifiques de niveau recherche, publiés ou non, émanant des établissements d'enseignement et de recherche français ou étrangers, des laboratoires publics ou privés. 


\section{Accepted Manuscript}

Characteristics of an urban fish assemblage: distribution of fish associated with coastal marinas

B.G. Clynick

PII:

S0141-1136(07)00092-X

DOI:

10.1016/j.marenvres.2007.07.005

Reference:

MERE 3137

To appear in:

Marine Environmental Research

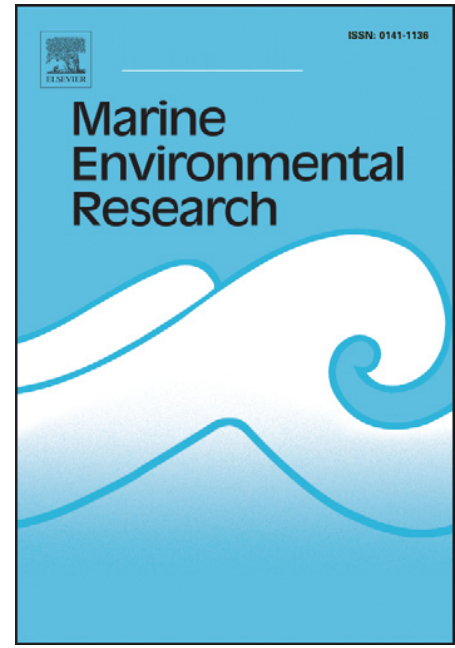

Received Date: $\quad 16$ June 2006

Revised Date: $\quad 28$ June 2007

Accepted Date: $\quad 4$ July 2007

Please cite this article as: Clynick, B.G., Characteristics of an urban fish assemblage: distribution of fish associated with coastal marinas, Marine Environmental Research (2007), doi: 10.1016/j.marenvres.2007.07.005

This is a PDF file of an unedited manuscript that has been accepted for publication. As a service to our customers we are providing this early version of the manuscript. The manuscript will undergo copyediting, typesetting, and review of the resulting proof before it is published in its final form. Please note that during the production process errors may be discovered which could affect the content, and all legal disclaimers that apply to the journal pertain. 
Characteristics of an urban fish assemblage: distribution of fish associated with coastal marinas

\author{
B. G. Clynick
}

Centre for Research on Ecological Impacts of Coastal Cities, Marine Ecology Laboratories A11, University of Sydney, NSW 2006, Australia phone: 61 (0)2 47541952; fax: 61 (0)2 93516713 ;

email: bgclynick@yahoo.com.au 
Abstract

In the marine environment, artificial structures are not, in general, managed for their

10 value as habitat and are often built with no a priori expectation as to the assemblages which may colonise them. It may, however, become increasingly important to consider the value of such structures as habitat when decisions are made with respect to the management of artificial structures. This study investigates the role marinas play as habitat for fish by examining the distribution of fish associated with these urban developments and how this distribution relates to

15 the physical characteristics of marinas. Assemblages of fish associated with marinas in waterways around Sydney were sampled in August and December 2002 and May 2003. Counts were done around structures present at marinas, i.e. pontoons and pilings and in the open water immediately adjacent to these structures. Within marinas, spatial patterns were particular to the types of fish examined. Large mobile species, such as Acanthopagrus australis and Girella

tricuspidata, moved between structures and the open water between them. Smaller species, such as Trachinops taeniatus and Microcanthus strigatus, were found only in the immediate vicinity of these structures. At a larger spatial scale, assemblages of fish varied markedly between different marinas. This variability could not, however, be attributed to the depth of water, the age or size of marinas, nor the type of material with which marinas were constructed (i.e.

25 pontoons or jetties).

Keywords: Artificial habitats; Estuaries; Fish; Marinas; Spatial scale

\section{Introduction}

Throughout the world, degradation and alteration of coastal ecosystems continues at an alarming rate (Hinrichsen, 1998). The extensive changes to marine habitats have included the

30 addition of artificial structures in waterways surrounding coastal cities (Burdick \& Short, 1999; Connell \& Glasby, 1999; Thompson et al. 2002; Chapman, 2003). These range from pontoons, pier-pilings and jetties used in the construction of foreshore developments, such as marinas, to breakwaters and seawalls that are built to protect foreshores. For example, in Sydney Harbour, at least $50 \%$ of the foreshore is now artificial seawalls (Chapman, 2003) and there are about 40 
35 functioning marinas that service 35,000 registered recreational vessels (Widmer \& Underwood, 2003). Similar trends in the increase of artificial structures have occurred in other parts of the “developed” world, particularly Europe (Smith \& Jenner, 1995) and the USA (Hollin, 1992).

Following this trend, current ecological research in urbanised coastal waters has examined whether built structures are creating novel habitats that support a different suite of

40 animals and plants than do natural habitats, or, alternatively, if species can use artificial structures in lieu of natural habitat (Glasby, 1999; Chapman \& Bulleri, 2002; Bulleri \& Chapman, 2004). Artificial structures introduced to intertidal and subtidal habitats may replace natural hard substrata or soft sediment. Therefore, the creation of such habitats has the potential to alter the distribution, diversity and abundance of organisms in these environments

45 (McDonnell \& Pickett, 1990; Connell \& Glasby, 1999), although the degree to which they alter biodiversity will depend on the type of natural habitat most affected (Bulleri, 2005).

Much research has focused on artificial structures as fish attraction devices (Molles, 1978; Grant et al. 1982; Carr \& Hixon, 1997; Rilov \& Benayahu, 2000) and countless studies have claimed that the presence of artificial structures can contribute to increasing fish biomass

50 (Bohnsack, 1989; Fabi et al. 2004). Few studies have, however, documented patterns of the spatial distribution of fish assemblages associated with artificial structures. Coastal developments, such as marinas, add novel habitats, including pontoons, pilings and jetties, to the marine environment. Different types of artificial structures differ in a number of respects, especially in their orientation, depth and composition, which may influence the types of organisms inhabiting them (Glasby \& Connell, 2001; Chapman \& Bulleri, 2002). Recent studies that have compared intertidal and/or subtidal assemblages living on different types of artificial structures have generally found that each type of structure, e.g. pontoons, pilings, seawalls, is inhabited by a different assemblage of organisms (e.g. Glasby, 1999; Glasby \& Connell, 2001). Such studies have, however, only dealt with organisms that live directly on the substratum

60 (People, 2006). The influence of these different types of structures on fish assemblages is not known. 
This study investigates the role marinas play as habitat for fish in an urban coastal ecosystem. The first aim of this study was to identify spatial patterns in the distribution of fish within marinas to examine the potential effects of different components of habitat on the distribution of fish in these artificial habitats. Specifically, we tested the hypothesis that the composition of fish assemblages and the number of fish would differ among different habitats (pontoons, pilings and the open water immediately adjacent to these structures) within marinas. To determine the generality of patterns, this hypothesis was tested at several locations and at several times.

Furthermore, as the effects of habitat on fish may be dependent on the spatial scale examined, the second aim of this study was to determine if marinas that are constructed of different materials and thus provide different types of habitats, differ with respect to the associated fish assemblages. This was done by testing the hypothesis that marinas with pontoons, i.e. pilings with an adjacent pontoon, and marinas with jetties, i.e. pilings with no adjacent pontoon, are consistently different with respect to the types and abundance of fish associated with them.

\section{Materials and methods}

\subsection{Study locations}

Fish assemblages associated with marinas were sampled at four sheltered locations in each of two waterways in Sydney, NSW, Australia; Sydney Harbour and Pittwater (Fig. 1). The selection of marinas was based on the need for sufficient visibility to allow visual census. The marinas used in this study have all been in operation for over 20 years and all support at least 30 boats and some, more than 100 boats. Some are constructed of wooden jetties and wooden pilings. Others have floating pontoons and pylons. Therefore, not all habitats (specifically pontoons) were present at every marina (Table 1). All marinas were built over soft sediment at depths varying from $4 \mathrm{~m}$ to $12 \mathrm{~m}$.

\subsection{Experimental methods}


To test hypotheses about the spatial distribution of fish within and among marinas at different times of the year, sampling was done in August 2002 (austral winter), December 2002

90 (austral summer) and May 2003 (austral autumn). Differences between the fish assemblages, the number of species of fish and the abundances of common species were examined at different spatial scales. At each marina, fish were sampled visually using stationary point counts within different areas of the marinas; under pontoons (if present), around pilings and in the open water between structures. Visual counts do have specific limitations, such as underestimating cryptic

95 fish (Sale \& Sharp 1983) and under- or over-estimating 'diver-negative' and 'diver-positive' fish species, respectively (Thresher \& Gunn 1986). Potential biases, however, should be consistent among locations. Furthermore, stationary point counts were chosen as they are appropriate when estimating the abundance of fish in small areas (Connell et al. 1998). This technique involves visually counting fish in a defined area for a defined period of time.

100 Although the small size of area sampled may reduce the number of fish counted and be biased to more mobile species, it was deemed appropriate to enable a comparison between different habitats within a marina. Because the fish assemblages at different depths were likely to be different, counts around pilings and in open water were done at the surface and bottom. Fish were counted $1 \mathrm{~m}$ either side of the diver and $2 \mathrm{~m}$ in front in a semi-circle formation. This was

105 the maximal area that could be sampled without counting fish that may be associated with adjacent habitats. Although the orientation of pontoons and pilings differed, comparable amounts of each habitat were sampled in each count. Surface counts were done from the surface to a depth of $2 \mathrm{~m}$ and bottom counts were done from the bottom to $2 \mathrm{~m}$ above the bottom. This depth was chosen to not confound surface and bottom counts. Four 3 minute counts (determined

110 by a pilot study) were done in each habitat at the surface and at the bottom. The count began when the diver approached the piling/pontoon. Small cryptic species were counted at the completion of the count by slowly swimming around the structure and closely inspecting the substratum.

\subsection{Statistical methods}


Differences in fish assemblages among marinas and among habitats within marinas were tested using non-parametric multivariate analyses of variance (described as NPMANOVA; Anderson, 2001) using Bray-Curtis measures of dissimilarity (Bray \& Curtis, 1957) calculated from untransformed data. Significance of all NP-MANOVA analyses were determined from 999 permutations of the data. Because complex multivariate interactions make 120 multi-factor designs difficult to interpret ecologically because of the many components that can contribute to differences, two separate analyses were done. First, for each sampling time and depth, two factor analyses were done to test for differences between the two estuaries and marinas within the estuaries. Second, at each depth, each marina was analysed separately to test for differences among habitats within marinas and among sampling times. Surface and bottom

125 counts were analysed separately because these two depths were assumed to support different assemblages. To test for differences between marinas with jetties compared to those with pontoons, the assemblages associated with the pilings at the surface were compared at each time of sampling using a two factor NP-MANOVA. The analysis consisted of the two types of marinas (with jetties or pontoons), with three marinas nested in each type and four replicate 130 counts at each marina (two marinas with pontoons were excluded from the analysis). Using the Primer software package, non -metric multidimensional scaling (nMDS) plots were used to illustrate spatial patterns of assemblages of fish in different habitats (Clarke, 1993). Averages were used in all nMDS ordinations because of the large stress values when using individual counts. Between-group similarities (SIMPER; Clarke, 1993) were used to determine the taxa

135 most responsible for any significant multivariate differences among assemblages.

Analysis of variance (ANOVA) was used to test for differences in the total number and types of fish and the abundance of common species between habitats and marinas. Because the hypotheses were aimed to look for differences among habitats and locations within times, not for differences among times, each time was analysed separately. In addition, because pontoons 140 were not sampled at all marinas, this habitat was excluded from univariate analyses and differences between pontoons and pilings were examined using graphical representations. 
Frequencies of occurrence were also examined for each species across the different factors of interest in this study.

Relationships between the physical attributes of marinas and abundance and diversity of

145 fish were tested using linear regressions. Age of the marina (yr), size of marina (number of berths), water depth (m) and distance from mouth of the estuary $(\mathrm{m})$ were regressed against the abundance and number of species of fish. The different physical factors were not correlated $(P>$ 0.05 ) and therefore relationships between the abundance and diversity of fish and each factor were examined separately.

\section{3. Results}

Fifty species of fish from 29 families were counted in Sydney Harbour. Twenty six species from 20 families were counted in Pittwater. Twenty four species were recorded in both estuaries (Table 2). A few species, including A. australis (bream), G. tricuspidata (luderick), $T$. taeniatus (hula fish) at both depths, M. strigatus (stripey) at the surface and Trachurus

155 novaezelandiae (yellowtail) at the bottom, were relatively common at some locations at some times. Most other species were relatively uncommon and patchy in their occurrence (Table 2).

\subsection{Patterns among habitats}

Across all locations and times of sampling, 51 species were found around structures; 50 around pilings and 22 around pontoons. These species were equally distributed at the surface

160 and bottom within marinas. Twenty species were counted in the open water adjacent to structures, the majority of which were counted at the bottom. Out of a total of 52 species, 28 were only seen directly adjacent to structures, including T. taeniatus and M. strigatus. Several of these species were only counted around pontoons or pilings and were only sighted on one or two occasions (Table 2).

The nMDS plots based on abundances of species generally suggested that assemblages associated with structures (pontoons and pilings; grey and black symbols) differed from those in open water (empty symbols), at the surface and the bottom within marinas (illustrated for December 2002 in Fig. 2). NP-MANOVA did not, however, detect significant differences at 
every marina at every time (at $P<0.05$ ). Fish assemblages did not differ between pontoons and

170 pilings (Fig. 2), except at Clontarf Marina and at Holmeport Marina in August ( $F=10.84,3.32$; respectively; $P<0.01)$.

Although over 30 species were found at any one time, relatively few contributed much to differences among habitats. In fact, generally 80 percent of the overall dissimilarity between habitats was accounted for by seven species at the surface and four species at the bottom (Table

175 3). At the surface, T. taeniatus was most important at distinguishing assemblages around pontoons and pilings from those in open water. A. australis was the main contributor to the dissimilarity between pilings and open water at the bottom (Table 3). Other contributions were largely from other species that were abundant around structures and absent from open water, e.g. Parablennius intermedius (horned blenny) and M. strigatus, or mobile schooling species

180 that occurred in open water, e.g. T. novaezelandiae.

At the surface, a greater number of fish and number of species were associated with both types of structure than with the open water (illustrated for December 2002 and May 2003 in Fig. 3a \& b). These differences were not, however, significant at every marina at every time (number of fish, $F=2.70,4.71,1.16$ for Time $1-3$, respectively; number of species, $F=4.02$,

$1853.70,3.08$ for Time $1-3, P<0.05$ for Location $x$ Habitat interaction). The average numbers of A. australis and G. tricusidata also tended to be greater around structures at the surface (illustrated for December 2002 in Fig. 4a \& b), but due to the large variance associated with these counts these differences were generally not significant $(P>0.05)$. Their frequency of occurrence was, however, generally much greater around structures than in the open water at the surface (Table 2). Pontoons and pilings, conversely, tended to support similar numbers and types of fish (Fig. 3a \& b). The abundances of both T. taeniatus and M. strigatus were very variable among both types of structures, with occasionally very large numbers under pontoons, but neither structure consistently supported a greater abundance of either species (Fig. 4c \& d).

At the bottom within marinas, there was consistently a greater number of species around 195 pilings than in the surrounding open water, but this difference between the two types of habitat 
was only significant in May (Fig. $5 \mathrm{~b} ; F=304.57, P<0.05$ ). Greater numbers of fish were also generally associated with pilings than with the open water at the bottom within marinas, although differences were not generally significant (Fig. 5i). In contrast, numbers of $A$. australis, G. tricuspidata and T. novaezelandiae showed variation among marinas and times but were not consistently different between the two habitats (illustrated for A. australis and G. tricuspidata in August 2002 in Fig. 6a and b).

\subsection{Patterns among marinas}

NP-MANOVA indicated that there was no significant difference in fish assemblages associated with marinas between the two estuaries $(P>0.05)$. Significant differences were detected in fish assemblages among marinas in both estuaries at the surface $(F=2.04,2.56,2.24$ for Time $1-3$, respectively; $P<0.05)$ and the bottom $(F=2.00,2.55,2.36$ for Time $1-3$, respectively; $P<0.05)$. Pairwise comparisons between all locations were highly significant across all times. The total abundance, number of species and abundances of common species was also very variable between different marinas within each estuary (Fig. 3 - 6). Differences

210 among marinas could not, however, be attributed to the presence or absence of pontoons. Marinas constructed with pontoons and those built with jetties were compared by analysing differences between surface counts around pilings. The nMDS plots did not reveal a separation between counts done at marinas with pontoons and marinas with jetties (Fig. 7) and no significant difference was found between these two types of marinas $(P>0.05)$. No consistent

215 pattern was detected between the two types of marinas when the total number of species and abundance of most common species were analysed (illustrated for December 2002 in Fig. 8). The exception to this was the abundance of G. tricuspidata, which appeared to be greater at marinas with pontoons at all times (Fig. 8c) and was significantly greater at time $1(F=8.37, P$ $<0.05)$.

\subsection{Physical attributes of marinas}

The number of fish $\left(P<0.01 ; r^{2}=0.28\right)$ and number of species $\left(P<0.01 ; r^{2}=0.33\right)$ of fish decreased with increasing distance from the mouth of the estuary. In contrast, age and size 
of the marina and water-depth were not significantly related to the abundance $\left(P>0.05 ; r^{2}=\right.$ $0.06,0.17,0.01$ respectively), nor diversity of fish $\left(P>0.05 ; r^{2}=0.01,0.14,0.04\right.$ respectively).

The number of species present and the total abundance of fish differed among times of sampling (Figs. 3 \& 5). Number of species was smallest in August (austral winter; $\mathrm{N}=31$ ) and greatest in December (austral summer; $\mathrm{N}=47$ ) and the abundance of common species tended to peak in December (Figs. 3 \& 5). Spatial patterns in the fish assemblage among habitats and marinas were, however, consistent among times of sampling (Fig. 3 - 6) and differences in the abundance of common species between habitats persisted across sampling times, with the exception of M. strigatus which was only present in December 2002.

\section{Discussion}

This study investigated the role of marinas as habitat for fish in an urban estuary by examining the spatial distribution of fish assemblages associated with marinas. This basic knowledge of how natural processes generate variability of species in space and time is essential to predict how the deployment of coastal structures will influence local assemblages and will identify sustainable design options (Airoldi et al., 2005). Extensive descriptive and

240 observational data have been collected on the types of fish associated with artificial structures in many parts of the world. The main body of literature is about the colonisation of fish to artificial reefs, purpose-built or accidental (Bohnsack et al. 1997; Seaman, 2002). It is very evident that artificial habitats of all types attract many species of fish, sometimes within hours of their deployment (Molles, 1978; Grant et al., 1982; Cummings, 1994), yet few studies have

245 documented spatial patterns of fish associated with artificial structures not deployed specifically as habitat. Furthermore, there have been few attempts to identify the ecological processes that create and maintain patterns of distribution of fish in artificial habitats (Miller, 2002).

In this study, fish displayed very predictable spatial distributions around marinas. The majority of the dissimilarity between the assemblages associated with both types of structure 
250 and the open water at marinas was explained by two types of fish; larger mobile species, such as A. australis (bream) and T. novaezelandiae (yellowtail), that moved between the pilings and pontoons and the open water immediately surrounding the structures, and smaller species, such as T. taeniatus (hula fish), M. strigatus (stripey) and Mecaenichthys immaculatus (immaculate damsel) that were concentrated only around the pilings and pontoons themselves. In fact, more

255 than half the species observed during this study were only counted in the immediate vicinity of structures. This suggests that artificial structures, such as pontoons and pilings, have a strong effect on the distribution of fish.

Such spatial patterns may be determined by the way fish respond to either the physical or biological structure of the habitat. Small-bodied species that were dominant in counts directly 260 around pilings and pontoons are likely to be attracted to these structures because they provide a form of shelter and protection from predation (Hixon \& Beets, 1993), as well as exposure to food (Edgar, 1999; Mobley \& Fleeger, 1999). In particular, the dominance of planktivores, such as T. taeniatus and M. strigatus may be related to the vertical orientation of pilings. Vertical structures allow access to plankton over a large depth range whilst providing shelter from

265 predators (Hamner et al. 1988). In other cases, small-bodied fish such as Blennidae and Tripterygiidae (Threefins) may find suitable habitat in the biogenic structures, such as mussels and algae, growing on pilings and pontoons. Love et al. (2000) observed large abundances of rock fish associated with mussel shells on and underneath offshore platforms in California.

Larger mobile species such as the Sparidae, A. australis and the Carangidae, $T$. novaezelandiae were common in all counts done at marinas and moved between structures and adjacent open water. Both these families are predatory fish that primarily feed on invertebrates associated with muddy/sandy substratum (Sparidae), or on zooplankton and small fish (Carangidae) in the vicinity of hard structures (Kuiter, 2000). Therefore, these species may obtain much of their food from the sandy bottom or water column around the marina (Steimle \& 275 Figley, 1996). 
Although the two depths sampled in this study were not compared directly, it is of interest to compare patterns of distribution of fish at the surface and bottom of marinas. Patterns among pilings persisted at both depths and fish associated with pilings were equally distributed between the two depths. Artificial structures, such as pilings, extend through the water column and therefore have a unique facility of being able to attract fish at all depths from the bottom to the surface. This is in contrast to natural rocky reefs, where depth is often positively correlated with the abundance and diversity of fish as a result of greater structural complexity at depths (Roberts \& Ormond, 1987).

In open water, very few fish were observed at the surface relative to the number

285 observed at the bottom. Species that moved between pilings and the water surrounding pilings e.g. A. australis and G. tricuspidata did so largely at the bottom of marinas, which was evident from the absence of these species in open water counts done at the surface. This spatial pattern may relate to a behavioural preference, such as a defence against predation in open water (Bohnsack et al. 1991; Rilov \& Benayahu, 1998).

A useful perspective for approaching and managing impacts is to identify changes in the environment from one state to another (Knowlton, 1992). As marinas are generally built over sand, they replace soft sediment with hard substrata. In such instances it is not possible to preserve the natural patterns of organisms, but it may be possible to minimise changes to patterns of distribution of organisms (Bulleri, 2005). For example, species that were present in

295 bottom counts also included species associated with sandy substrata that have little affinity to hard substrata, such as Gobidae, Upeneus tragula (goatfish) and Urolophidae (stingrees). These species were most likely present prior to the building of marinas and other structures. It is not possible to ascertain whether these species were present in similar numbers to those prior to the marina being built, or if, in fact, they were present at all, as no before-comparisons were done in

300 this study. Previous studies have, however, shown that species generally associated with soft sediment are often present in similar abundance on the soft sediment under marinas as they are in sandy habitats where there is not additional structure (Alevizon \& Gorham, 1989; Barnes, 1999). 
Interestingly, there appeared to be no difference in the types and numbers of fish associated with pilings from those found under pontoons despite the different nature of these two types of structures. These results differ from those of the majority of research comparing intertidal and/or subtidal assemblages living on different types of artificial structures. Generally, researchers have found each type of structure, e.g. pontoons, pilings, seawalls, is inhabited by a distinct assemblage of organisms (e.g. Glasby, 1999; Glasby \& Connell, 2001; People, 2006).

310 These studies have, however, only dealt with organisms that live directly on or in biogenic habitat on the substratum.

The response of organisms to habitat is largely dependent on the mobility of the species being investigated (Jaenike \& Holt, 1991). In reef-fish systems, the size of an individual's home range or the extent of its daily foraging activities will directly contribute to the scale at which its

315 habitat is perceived (Chesson, 1998). The majority of fish associated with pilings and pontoons in this study move over distances at the scale of metres. Therefore, it is probable that fish are not responding to pontoons and pilings as distinct habitats, but rather respond to them at a larger spatial scale, e.g. an area of the marina that has both pontoons and pilings.

When the importance of these separate habitats was examined at the scale of marinas,

320 i.e. marinas that have both pontoons and pilings versus marinas that only have pilings, no difference between the two types of marinas was found. This provided further evidence that the presence of pontoons in marinas does not alter the associated fish assemblage. There was, however, considerable spatial variability in the abundance and composition of fish assemblages among different marinas within the same estuary. These differences could not be attributed to differences in water depth, size nor age of the marinas. In contrast, the abundance and diversity of fish were greater at marinas close to the mouth of the estuary. In general, species diversity tends to decrease with increasing distance from the ocean, which may be a function of larval supply and food availability (Jackson \& Jones, 1999). In this study, however, this result may also be partly attributed to the relative proximity of these outer marinas to natural rocky reefs.

330 For example, Davis Marina, which had consistently greater numbers and diversity of fish than the other marinas, is located within several hundred metres of an extensive natural rocky reef. 
Although the two habitats are separated by bare sand which may limit movement of many species (Bell \& Westoby, 1986), other species can leave the reef to forage in open water and, therefore, may find other habitat following excursions from natural reefs (Leis et al., 2002). Temporal variability of fish assemblages at different scales can be quite large and may confound spatial patterns of fish among different habitats (Connell \& Kingsford, 1998). In this study, the relative abundances of species fluctuated over the three sampling times. This may have been a result of seasonal recruitment of some numerically dominant species (Sale et al. 1994). It was evident, however, that patterns across the different spatial scales, i.e. habitats within marinas and marinas, persisted over time. Previous studies have also suggested that relative abundances among sites may not be affected by large changes in fish abundances over time (Holbrook et al. 1994; Curley et al. 2002)

Marinas in estuaries surrounding Sydney appear to be functioning as habitat for fish. The spatial variation in the fish assemblages associated with marinas clearly indicated that fish are responding to the presence of structures within marinas. Different types of structures, in this instance, pontoons and pilings, and different types of marinas, those built with pontoons and those built with jetties, however, did not differ with respect to their associated fish assemblages. The large variability between marinas also could not be attributed to differences in the size, age and depth of marinas. This variability among marinas makes it difficult to predict the impacts of

350 a marina in a specific area and further research will need to be carefully designed to identify and quantify site-specific impacts. Furthermore, while it is still essential to minimize the effects of marinas on surrounding habitats and biota, it may also be possible to identify design options that maximise their provision of habitat for important species of fish. Information of what changes might be beneficial or cost effective is not yet known. This information will come from field experiments, where managers of marinas make their resources available and collaborate with researchers to investigate different options. Results from such research will also be broadly applicable to all types of hard artificial structures present in urban waterways.

\section{Acknowledgements}


I thank M.G. Chapman and A.J. Underwood for their help and guidance though out this study. I thank D. Blockley, J.J Cruz, S. Cummins and G. Kaplan for help with field work. I am grateful to C. McKindsey and two anonymous referees for useful comments on the manuscript. Funds were provided by an Australian Postgraduate Award and the Australian Research Council Special Research Centre Grant to the Centre for Research on Ecological Impacts of Coastal Cities.

\section{References}

Airoldi, L., Abbiati, M., Beck, M.W., Hawkins, S.J., Jonsson, P.R., Martin, D., Moschella, P.S.,

Sundelöf, A., Thompson, R.C., \& Åberg, P. (2005). An ecological perspective on the deployment and design of low-crested and other hard coastal defence structures. Coastal Engineering, 52, 1073-1087.

Alevizon, W.S., \& Gorham, J.C. (1989). Effects of artificial reef deployment on nearby resident fishes. Bulletin of Marine Science, 44, 646-661.

370 Anderson, M.J. (2001). A new method for non-parametric multivariate analysis of variance. Austral Ecology, 26, 32-46.

Barnes, P. B. (1999). Influences of marinas on assemblages of fish in Sydney Harbour. Honours thesis, University of Sydney.

Bell, J.D., \& Westoby, M. (1986). Variation in seagrass height and density over a wide spatial scale: effects on common fish and decapods. Journal of Experimental Marine Biology and Ecology, 104, 275-295.

Bohnsack, J.A. (1989). Are high densities of fishes at artificial reefs the result of habitat limitation or behavioral preference. Bulletin of Marine Science, 44, 631-645.

Bohnsack, J.A., Eckland, A., \& Szmant, A.M. (1997). Artificial reef research: Is there more than the attraction-production issue? Fisheries, 22, 14-16. 
Bohnsack, J. A., Johnson, D. L., \& Ambrose, R. F. (1991). Ecology of artificial reef habitats and fishes. In W. Seaman Jr, \& L. M. Sprague (Eds.), Artificial habitats for marine and freshwater fisheries (pp. 61-107). San Diego: Academic Press.

Bray, J.R., \& Curtis, J.T. (1957). An ordination of the upland forest communities of southern 385 Wisconsin. Ecological Monographs, 27, 325-349.

Bulleri, F. (2005). The introduction of artificial structures on marine soft- and hard-bottoms: ecological implications of epibiota. Environmental Conservation, 32, 101-102.

Bulleri, F., \& Chapman, M.G. (2004). Intertidal assemblages on artificial and natural habitats in marinas on the north-west coast of Italy. Marine Biology, 145, 381-391.

390 Burdick, D.M., \& Short, F.T. (1999). The effects of boat docks on eelgrass beds in coastal waters of Massachusetts. Environmental Management, 23, 231-240.

Carr, M.H., \& Hixon, M.A. (1997). Artificial reefs: The importance of comparisons with natural reefs. Fisheries, 22, 28-33.

Chapman, M.G. (2003). Paucity of mobile species on constructed seawalls: effects of

395 urbanization on biodiversity. Marine Ecology Progress Series, 264, 21-29.

Chapman, M.G., \& Bulleri, F. (2002). Intertidal seawalls-new features of landscape in intertidal environments. Landscape and Urban Planning, 947, 1-14.

Chesson, P. (1998). Spatial scales in the study of reef fishes: A theoretical perspective. Australian Journal of Ecology, 23, 209-215.

400 Clarke, K.R. (1993). Non-parametric multivariate analyses of changes in community structure. Australian Journal of Ecology, 18, 117-143. 
Connell, S.D., \& Glasby, T.M. (1999). Do urban structures influence local abundance and diversity of subtidal epibiota? A case study from Sydney Harbour, Australia. Marine Environmental Research, 47, 373-387.

405 Connell, S.D., \& Kingsford, M.J. (1998). Spatial, temporal and habitat-related variation in the abundance of large predatory fish at One Tree Reef, Australia. Coral Reefs, 17, 49-59.

Connell, S.D., Samoilys, M.A., Lincoln-Smith, M.P., \& Leqata, J. (1998) Comparisons of abundance of coral-reef fish: Catch and effort surveys vs visual census. Australian Journal of Ecology, 23, 579-586

410 Cummings, S.L. (1994). Colonization of a nearshore artificial reef at Boca Raton (Palm Beach County), Florida. Bulletin of Marine Science, 55, 1193-1215.

Curley, B.G., Kingsford, M.J., \& Gillanders, B.M. (2002). Spatial and habitat-related patterns of temperate reef fish assemblages: implications for the design of Marine Protected Areas. Marine and Freshwater Research, 53, 1197-1210.

415 Edgar, G.J. (1999). Experimental analysis of structural versus trophic importance of seagrass beds. II. Effects on fishes, decapods and cephalopods. Life and Environment, 49, 249-260.

Fabi, G., Grati, F., Puletti, M., \& Scarcella, G. (2004). Effects of fish community induced by installation of two gas platforms in the Adriatic Sea. Marine Ecology Progress Series, 273, $187-$ 197.

420 Glasby, T.M. (1999). Differences between subtidal epibiota on pier pilings and rocky reefs at marinas in Sydney, Australia. Estuarine, Coastal and Shelf Science, 48, 281-290.

Glasby, T.M., \& Connell, S.D. (2001). Orientation and position of substrata have large effects on epibiotic assemblages. Marine Ecology Progress Series, 214, 127-135.

Grant, J.J., Wilson, K.C., Grover, A., \& Togstad, H.A. (1982). Early development of Pendleton 425 artificial reef. Marine Fisheries Review, 44, 53-60. 
Hamner, W.M., Jones, M.S., Carleton, J.H., Hauri, I.R., \& Williams, D.McB. (1988).

Zooplankton, planktivorous fish and water currents on a windward reef face: Great Barrier Reef, Australia. Bulletin of Marine Science, 42, 459-479.

Hinrichsen, D. (1988). Coastal waters of the world: Trends, threats, and strategies.

430 Washington, D.C.: Island Press.

Hixon, M.A., \& Beets, J.P. (1993). Predation, prey refuges and the structure of coral-reef fish assemblages. Ecological Monographs, 63, 77-101.

Holbrook, S.J., Kingsford, M.J., Schmitt, R.J., \& Stephens, J.S. (1994). Spatial and temporal patterns in assemblages of temperate reef fish. American Zoology, 34, 463-75.

435 Jackson, G., \& Jones, G.K. (1999). Spatial and temporal variation in nearshore fish and macroinvertebrate assemblages from a temperate Australian estuary over a decade. Marine Ecology Progress Series, 182, 253-268.

Jaenike, J., \& Holt, R.D. (1991). Genetic variation for habitat preference: evidence and explanations. American Naturalist, 137, S67-S90.

440 Knowlton, N. (1992). Thresholds and multiple stable states in coral reef community dynamics. American Zoologist, 32, 674-682.

Kuiter, R. H. (2000). Guide to sea fishes of Australia. Australia: New Holland Publishers.

Leis, J.M., Carson-Ewart, B.M., \& Webley, J. (2002). Settlement behaviour of coral-reef fish larvae at subsurface artificial-reef moorings. Marine and Freshwater Research, 53, 319-327.

445 Love, M.S., Caselle, J.E., \& Snook, L. (2000). Fish populations around seven oil platforms in the Santa Barbara Channel area. Fishery Bulletin, 98, 96-117.

McDonnell, M.J., \& Pickett, S.T.A. (1990). Ecosystem structure and function along urban-rural gradients: an unexploited opportunity for ecology. Ecology, 71, 1232-1237. 
Miller, M.W. (2002). Using ecological processes to advance artificial reef goals. ICES Journal of Marine Science, 59, S27-S31.

Mobley, K.B., \& Fleeger, W. (1999). Diet of Scartella Cristata: an artificial habitat-associated blenny (Pisces: Blenniidae). Life and Environment, 49, 221-228.

Molles, M.C. (1978). Fish species diversity on model and natural reef patches: experimental insular biogeography. Ecological Monographs, 48, 289-305.

455 People, J. (2006). Mussel beds on different types of artificial structures support different macroinvertebrate assemblages. Austral Ecology, 31, 271-281.

Rilov, G., \& Benayahu, Y. (2000). Fish assemblage on natural versus vertical artificial reefs: the rehabilitation perspective. Marine Biology, 136, 931-942.

Rilov, G., \& Benayahu, Y. (1998). Vertical artificial structures as an alternative habitat for coral 460 reef fishes in disturbed environments. Marine Environmental Research, 45, 431-451.

Roberts, C.M., \& Ormond, R.F.G. (1987). Habitat complexity and coral reef fish diversity and abundance on Red Sea fringing reefs. Marine Ecology Progress Series, 41, 1-8.

Sale, P.F., \& Sharp, B.J. (1983). Correction of bias in visual transect censuses of coral reef fishes. Coral Reefs, 2, 37-42.

465 Sale, P.F., Guy, J.A., \& Steel, W.J. (1994). Ecological structure of assemblages of coral reef fishes on isolated patch reefs. Oecologia, 98, 83-99.

Seaman, W. (2002). Unifying trends and opportunities in global artificial reef research, including evaluation. ICES Journal of Marine Science, 59, S14-S16.

Smith, C., \& Jenner, P. (1995). Marinas in Europe. Travel Tourism Analyst, 6, 56-72. 
470 Steimle, F.W., \& Figley, W. (1996). The importance of artificial reef epifauna to black sea bass diets in the Middle Atlantic Bight. North American Journal of Fisheries Management, 16, 433439.

Thompson, R.C., Crowe, T.P., \& Hawkins, S.J. (2002). Rocky intertidal communities: past environmental changes, present status and predictions for the next 25 years. Environmental

475 Conservation, 29, 168-191.

Thresher, R.E., \& Gunn, J.S. (1986). Comparative analysis of visual census techniques for highly mobile, reef-associated piscivores (Carangidae). Environmental Biology of Fishes, 17, 93-116.

Widmer, W.M., \& Underwood, A.J. (2003). Factors affecting traffic and anchoring patterns of recreational boats in Sydney Harbour, Australia. Landscape and Urban Planning, 66, 173-183. 
485

490

495

500

505

510

Pittwater
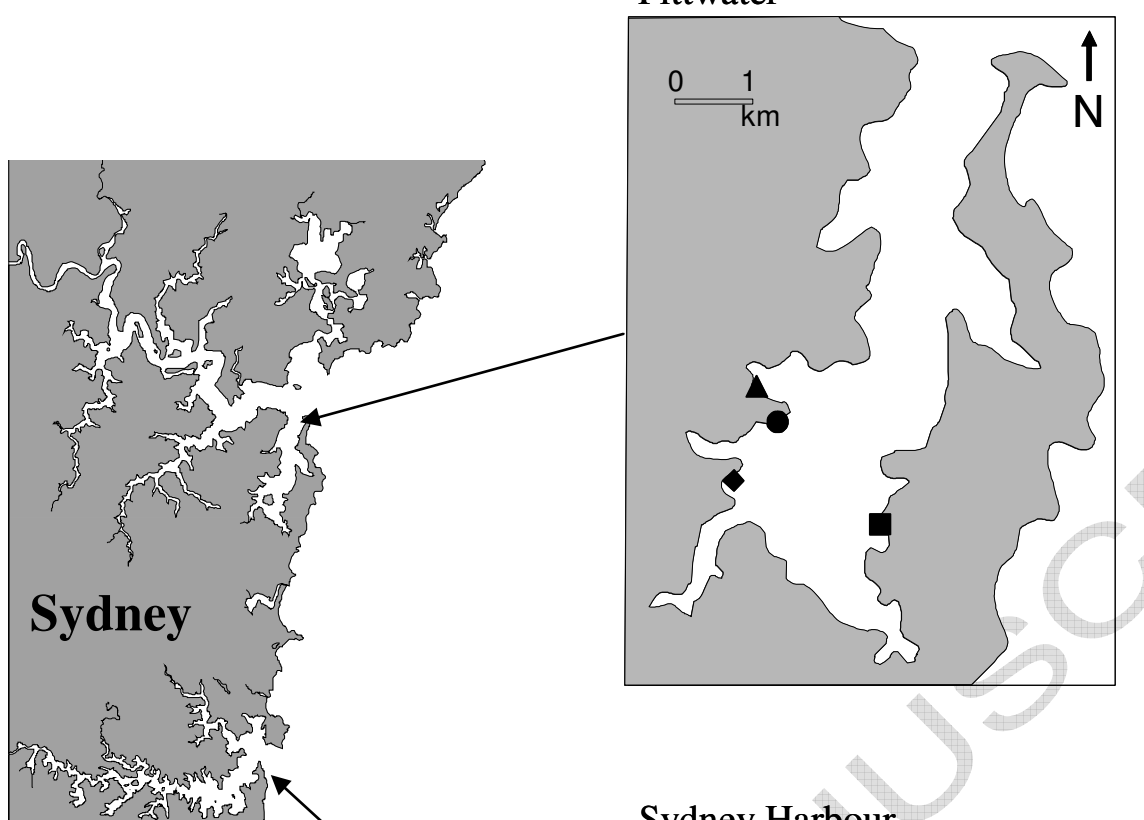

Sydney Harbour

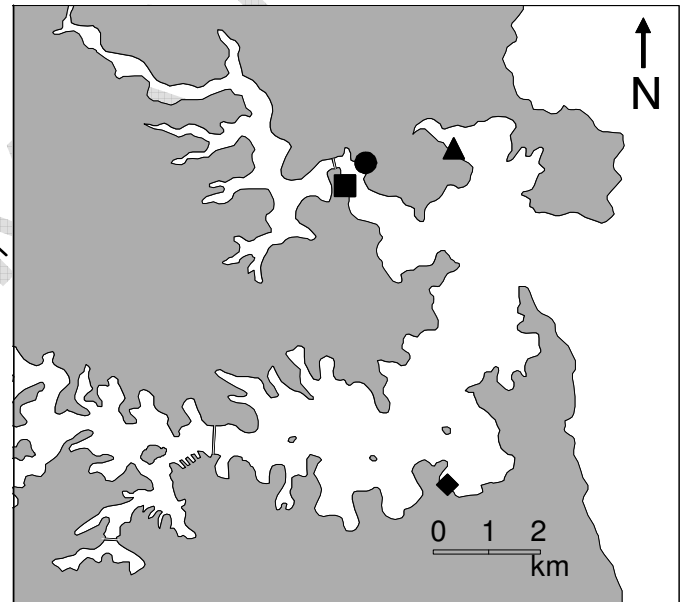

Fig. 1 Position of the four marinas in each waterway; Ferguson's Boatshed ( $\mathbf{\square})$, Clontarf Marina

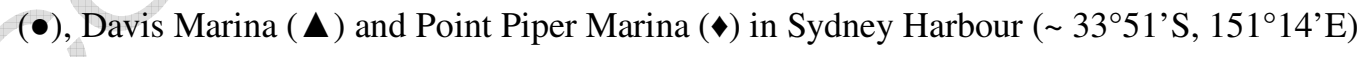

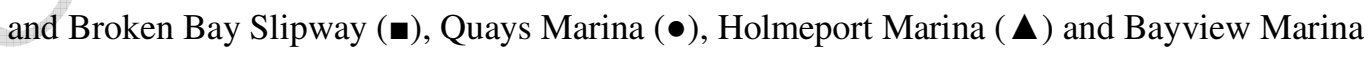
$520(\diamond)$ in Pittwater $\left(\sim 33^{\circ} 36^{\prime} \mathrm{S}, 151^{\circ} 16^{\prime} \mathrm{E}\right)$. 
(a)

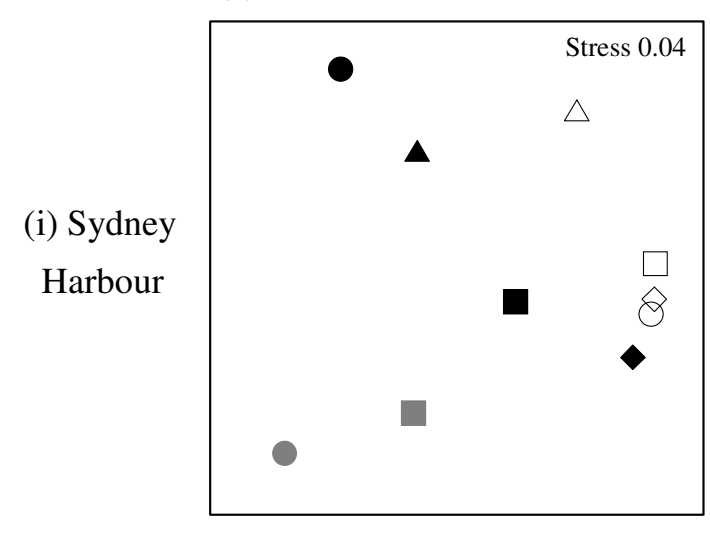

(b)
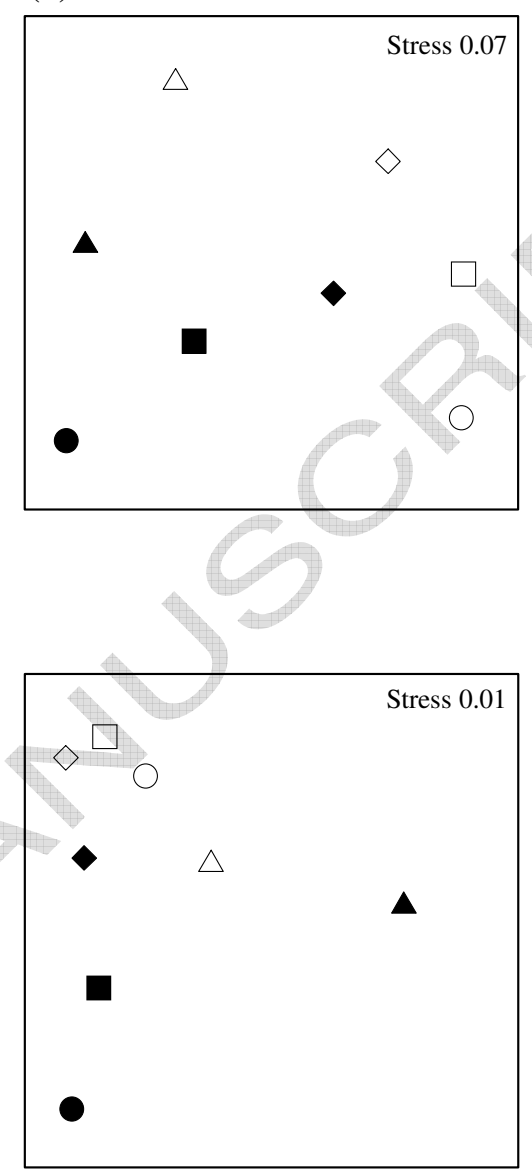

Fig. 2 nMDS ordinations comparing fish assemblages among the three habitats at the (a) surface and (b) bottom; pontoons (grey), pilings (black) and open water (white) in Dec. 2002 at (i) the four marinas in Sydney Harbour; Ferguson’s Boatshed ( $\square$ ), Clontarf Marina (०), Davis Marina

$525(\Delta)$ and Point Piper Marina $(\diamond)$ and (ii) the four marinas in Pittwater; Broken Bay Slipway ( $\square$ ), Quays Marina ( $\odot)$, Holmeport Marina $(\Delta)$ and Bayview Marina $(\diamond)$. Each point is a centroid of the replicates in each habitat at each marina. 
(a) Dec 2002
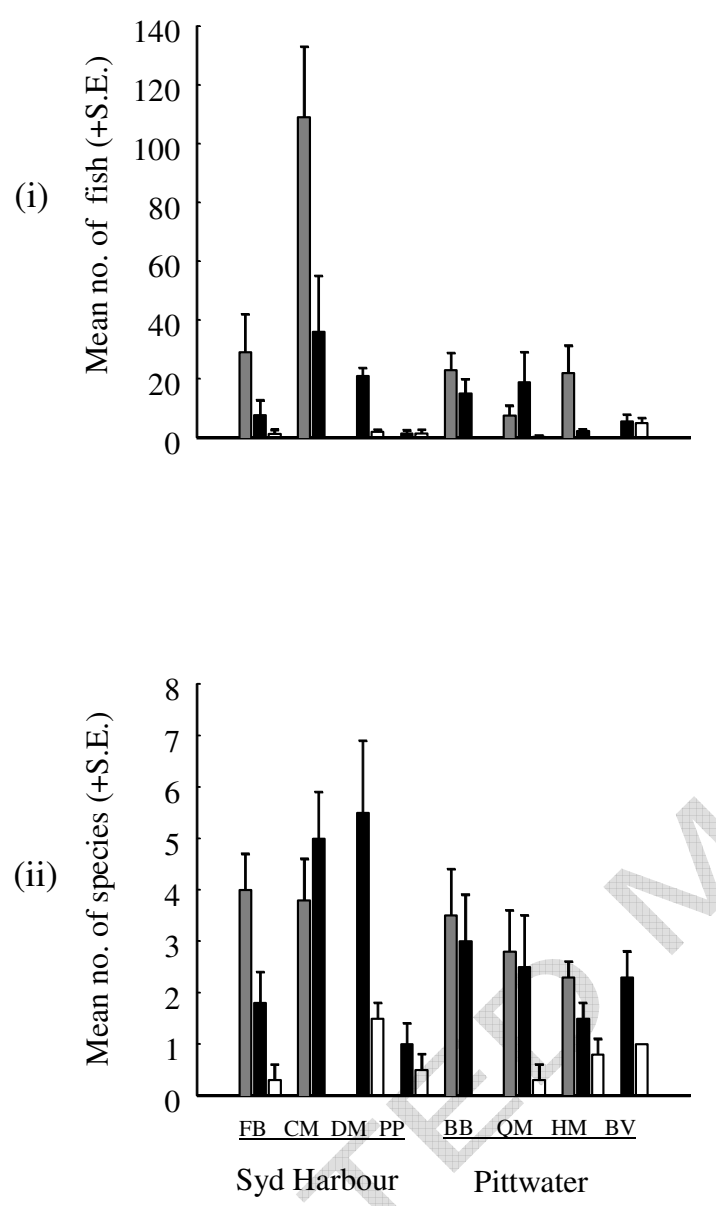

(b) May 2003
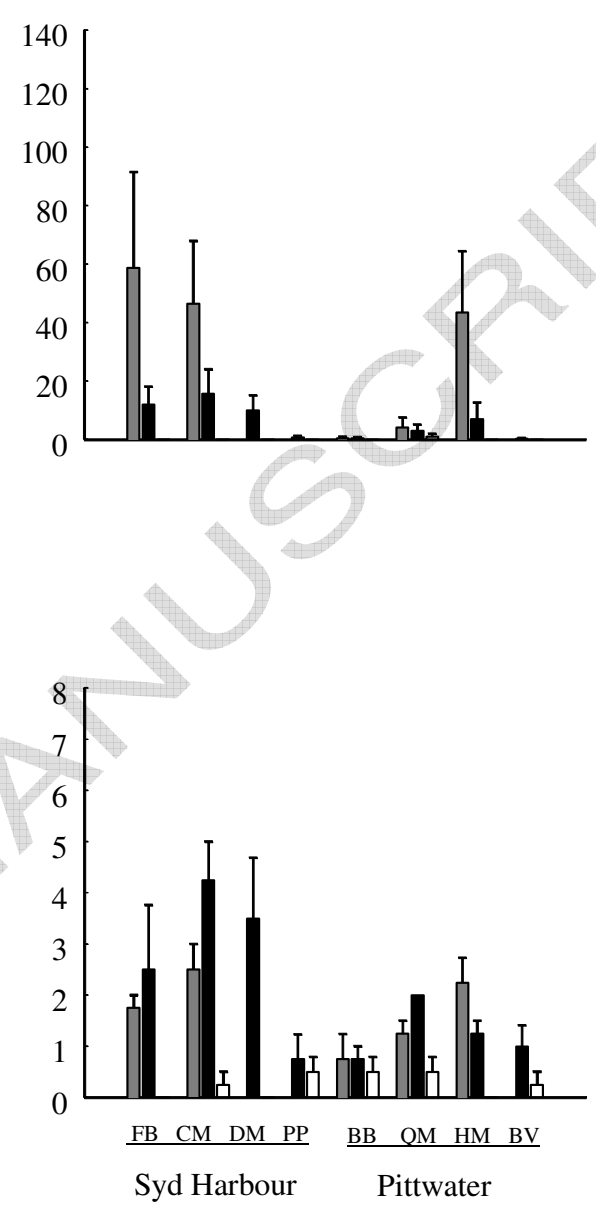

Fig. 3 Mean (+S.E.) number of (i) fish and (ii) species of fish in surface counts in (a) Dec. 2002, (b) May 2003 at the four marinas in Sydney Harbour and four marinas in Pittwater in the three habitats. Pontoons $=$ grey bars; Pilings $=$ black bars; Open water $=$ white bars. $n=4$. 
(a) Acanthopagrus australis

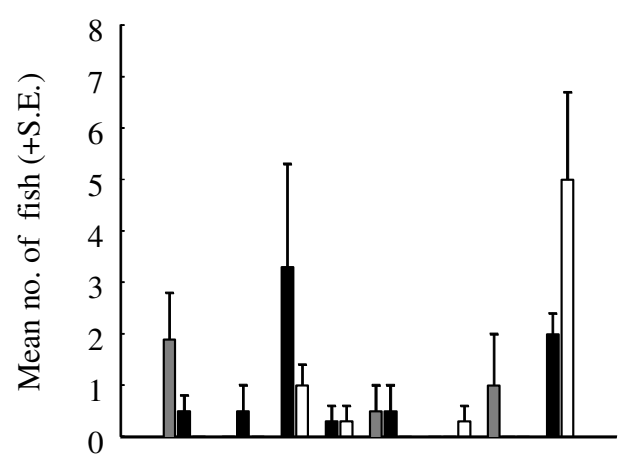

(c) Trachinops taeniatus

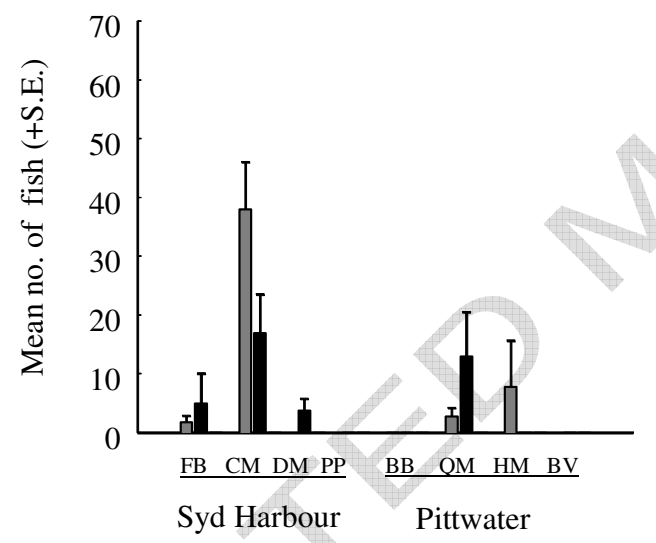

(b) Girella tricuspidata

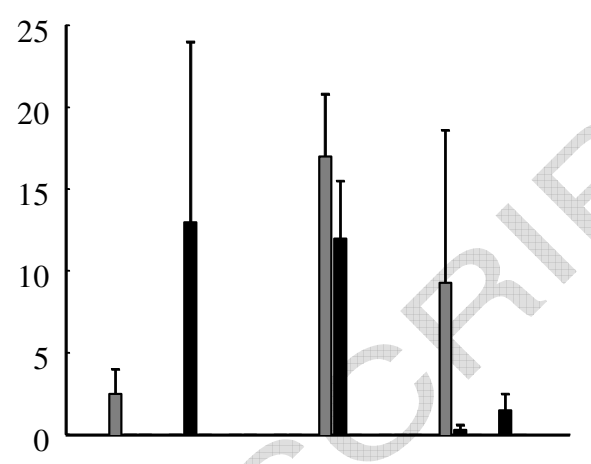

(d) Microcanthus strigatus

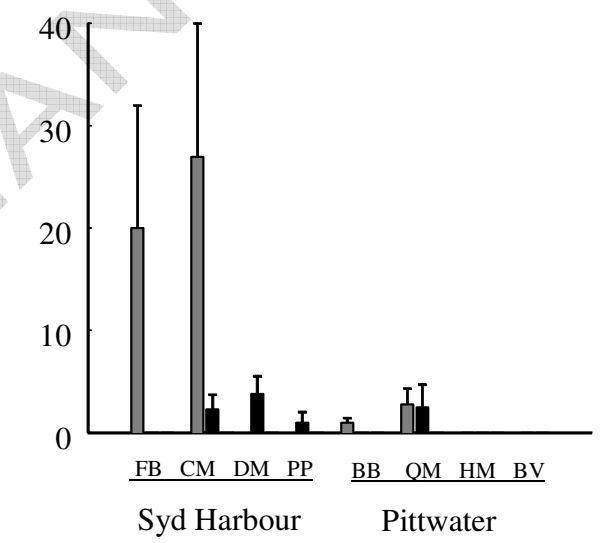

Fig. 4 Mean (+S.E.) abundances of common species in surface counts in Dec. 2002 at the four marinas in Sydney Harbour and four marinas in Pittwater in the three habitats. Pontoons $=$ grey bars; Pilings $=$ black bars; Open water $=$ white bars. $n=4$. 
(a) Dec. 2002
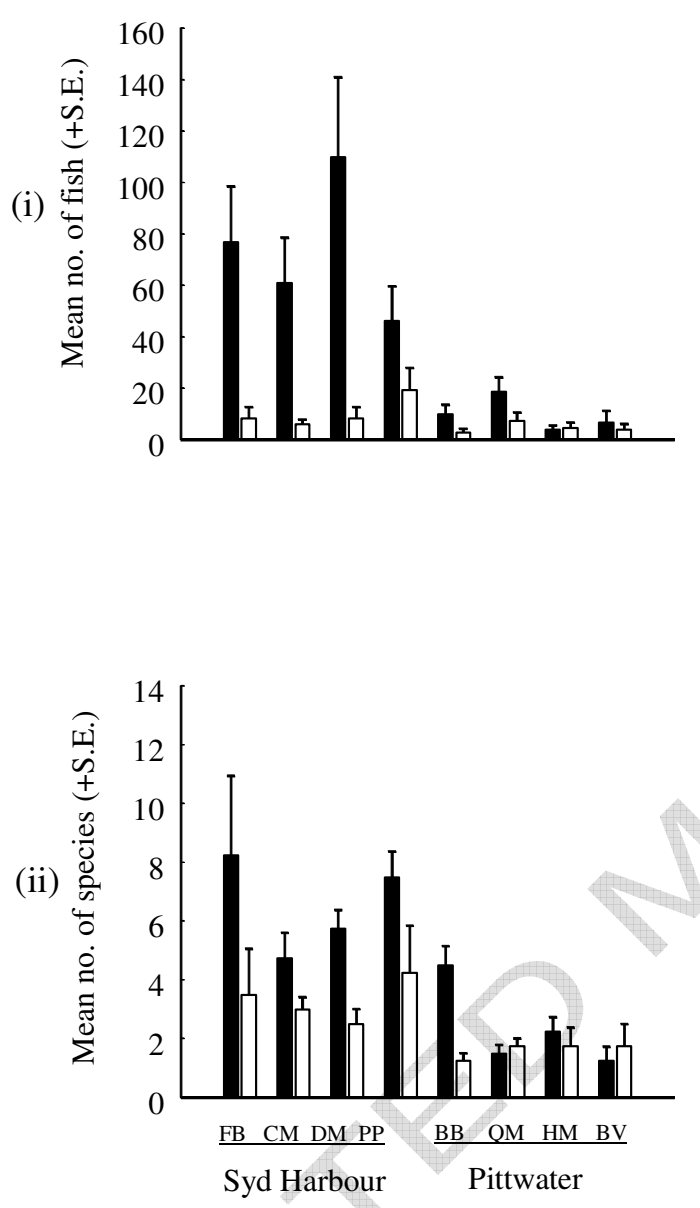

(b) May 2003
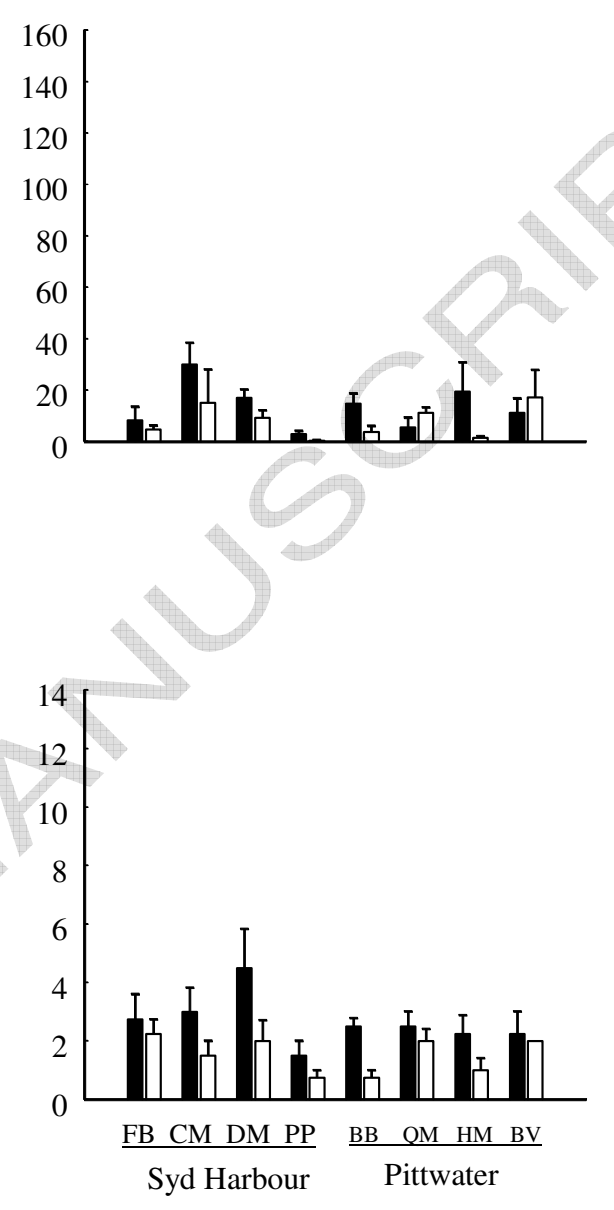

Fig. 5 Mean (+S.E.) number of (i) fish and (ii) species of fish in bottom counts in (a) Dec. 2002, (b) May 2003 at the four marinas in Sydney Harbour and four marinas in Pittwater in the two habitats. Pilings $=$ black bars; Open water $=$ white bars. $n=4$. 
(a) Acanthopagrus australis

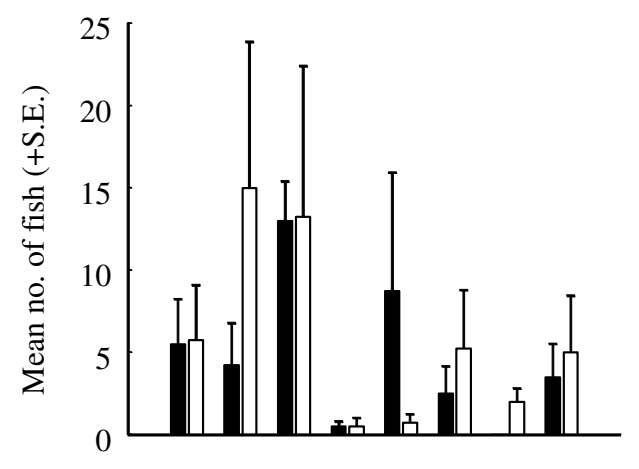

(b) Girella tricuspidata

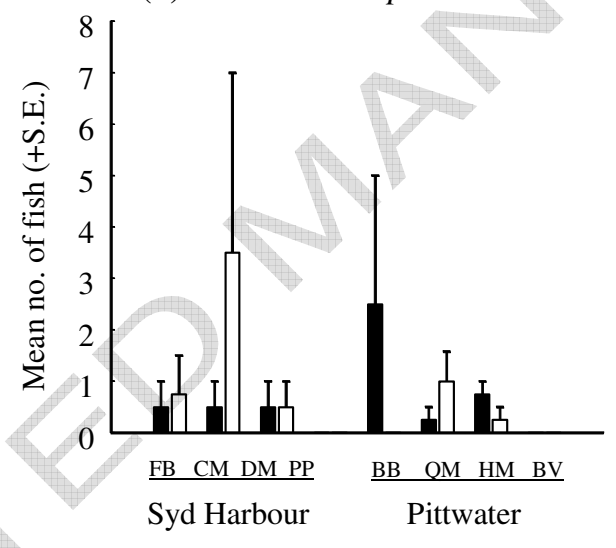

540

Fig. 6 Mean (+S.E.) abundance of (a) A. australis and (b) G. tricuspidata in bottom counts in Aug. 2002 at the four marinas in Sydney Harbour and four marinas in Pittwater in the two habitats. Pilings $=$ black bars; Open water $=$ white bars. $n=4$. 
(a) Time 1

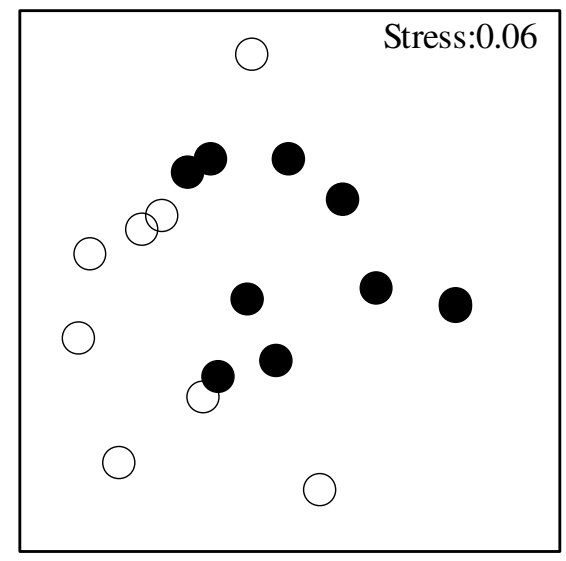

(b) Time 2

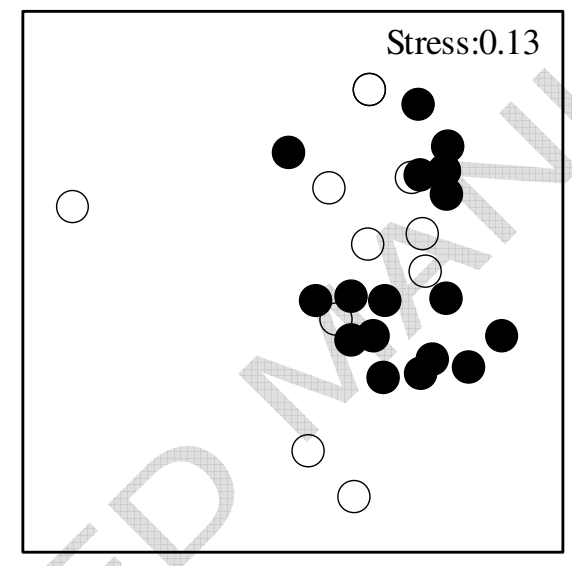

(c) Time 3

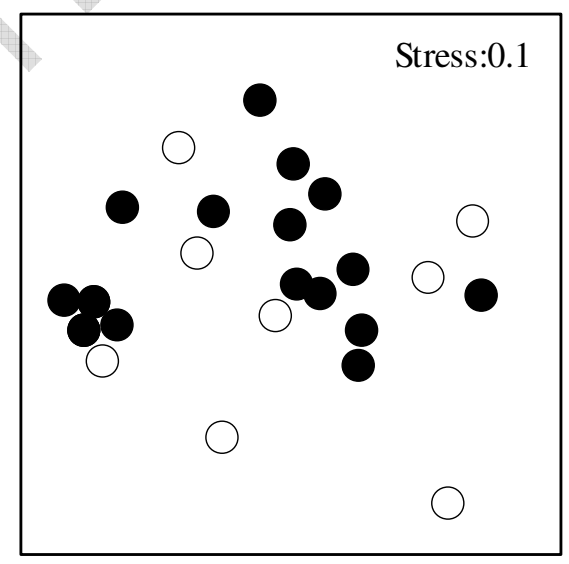

545 Fig. 7 nMDS ordinations comparing abundances of fish assemblages associated with pilings at marinas with pontoons (black) and marinas with jetties (white) at the three sampling times. $n=$ 4 
(a) Total no. of fish

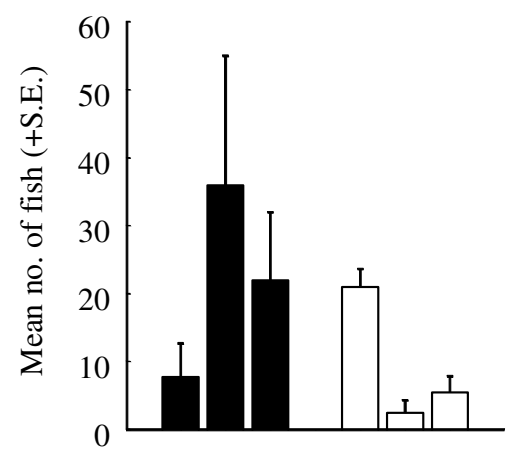

(c) Girella tricuspidata

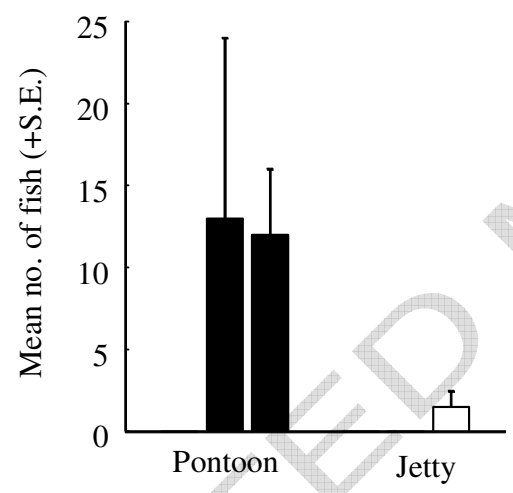

(b) Total no. of species

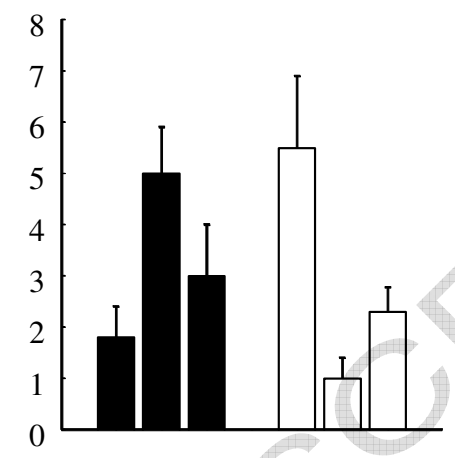

(d) Trachinops taeniatus

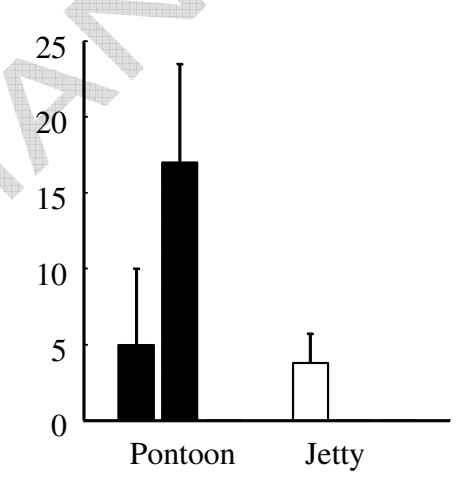

Fig. 8 Mean (+S.E.) number of (a) fish, (b) species of fish, (c) G. tricuspidata and (d) $T$. bars) in Dec. 2002. $n=4$. 
Table 1 The habitats sampled at each depth; $\mathrm{S}=$ surface and $\mathrm{B}=$ bottom, at each marina. $\mathrm{X}$ indicates that habitat was sampled.

\begin{tabular}{lcccc}
\hline & Depth & Pontoon & Piling & Open water \\
\hline Sydney Harbour & & & & \\
\hline Ferguson's Boatshed & $\mathrm{S}$ & $\mathrm{X}$ & $\mathrm{X}$ & $\mathrm{X}$ \\
& $\mathrm{B}$ & & $\mathrm{X}$ & $\mathrm{X}$ \\
Clontarf Marina & $\mathrm{S}$ & $\mathrm{X}$ & $\mathrm{X}$ & $\mathrm{X}$ \\
& $\mathrm{B}$ & & $\mathrm{X}$ & $\mathrm{X}$ \\
Davis Marina & $\mathrm{S}$ & & $\mathrm{X}$ & $\mathrm{X}$ \\
& $\mathrm{B}$ & & $\mathrm{X}$ & $\mathrm{X}$ \\
Point Piper marina & $\mathrm{S}$ & & $\mathrm{X}$ & $\mathrm{X}$ \\
& $\mathrm{B}$ & & $\mathrm{X}$ & \\
\hline Pittwater & & & $\mathrm{X}$ & $\mathrm{X}$ \\
\hline Broken Bay Slipway & & $\mathrm{X}$ & $\mathrm{X}$ & $\mathrm{X}$ \\
& $\mathrm{S}$ & $\mathrm{X}$ & $\mathrm{X}$ & $\mathrm{X}$ \\
Quays Marina & $\mathrm{B}$ & $\mathrm{X}$ & $\mathrm{X}$ \\
Holmeport Marina & $\mathrm{S}$ & $\mathrm{X}$ & $\mathrm{X}$ \\
Bayview Marina & $\mathrm{B}$ & $\mathrm{X}$ & $\mathrm{X}$ \\
\hline
\end{tabular}


555 Table 2 List of 52 species recorded and their frequency of occurrence around pontoons (Po), pilings (Pi) and open water (Ow), at marinas in Sydney Harbour and Pittwater (out of a possible 96 counts done around pilings and open water and 60 counts done around pontoons).

\begin{tabular}{|c|c|c|c|c|c|c|c|c|c|c|c|}
\hline \multirow[t]{3}{*}{ Family/Species } & \multicolumn{5}{|c|}{ Sydney Harbour } & \multicolumn{4}{|c|}{ Pittwater } & \multicolumn{2}{|c|}{20} \\
\hline & \multicolumn{3}{|c|}{ Surface } & \multicolumn{2}{|c|}{ Bottom } & \multicolumn{3}{|c|}{ Surface } & & \multicolumn{2}{|c|}{ Bottom } \\
\hline & Po & $\mathbf{P i}$ & Ow & $\mathbf{P i}$ & Ow & Po & & $\mathbf{P i}$ & Ow & $\mathbf{P i}$ & Ow \\
\hline Acanthuridae & & & & & & & & & & & \\
\hline Prionurus microlepidotus & & 2 & & 1 & & & & & & & \\
\hline Prionurus maculatus & & 1 & & & & & & & & & \\
\hline Apogonidae & & & & & & & & & & & \\
\hline Apogon limenus & & & & 2 & & & & & & 1 & \\
\hline Atherinidae & & & & & & & & 1 & 4 & 1 & \\
\hline Blenniidae & 17 & 5 & & 6 & & & & 23 & & 9 & \\
\hline Carangidae & & & & & & & & & & & \\
\hline Pseudocaranx dentex & & 2 & 3 & 3 & 4 & & & & & & \\
\hline Trachurus novaezelandiae & & & 1 & 12 & 9 & & & & & 6 & 4 \\
\hline Chandidae & & & & & & & & & & & \\
\hline Ambassis jacksoniensis & & 3 & 3 & 2 & 2 & & & 4 & & 6 & \\
\hline Cheilodactylidae & & & & & & & & & & & \\
\hline Cheilodactylus fuscus & & 1 & & 2 & & & & & & & \\
\hline Cheilodactylus vestitus & & & & 3 & & & & & & 1 & \\
\hline Chironemidae & & & & & & & & & & & \\
\hline Chironemus marmoratus & & 1 & & 2 & & & 1 & & & 1 & \\
\hline Diodonitidae & & & & & & & & & & & \\
\hline Dicotylichthys punctulatus & & & & 1 & 1 & & & & & 1 & \\
\hline Enoplosidae & & & & & & & & & & & \\
\hline Enoplosus armatus & & 1 & & & & & & & & & \\
\hline Gerreidae & & & & & & & & & & & \\
\hline Gerres subfasciatus & & & & 4 & 5 & & & & & 4 & 3 \\
\hline Girellidae & & & & & & & & & & & \\
\hline Girella tricuspidata & 8 & 6 & 1 & 6 & 4 & & 12 & 10 & 1 & 8 & 8 \\
\hline Gobiidae & & & & 14 & 13 & & & & & 6 & 12 \\
\hline Kyphosidae & & & & & & & & & & & \\
\hline Kyphosus spp. & 5 & & & 3 & & & & & & & \\
\hline Labridae & & & & & & & & & & & \\
\hline Achoerodus viridus & & & & 1 & & & & & & & \\
\hline Ophthalmolepis lineolate & 1 & & & 1 & & & & & & & \\
\hline Pseudolabrus guenrheri & 9 & 2 & & 6 & & & & & & & \\
\hline Pictilabrus laticlavius & & 1 & & 2 & & & & & & & \\
\hline Microcanthidae & & & & & & & & & & & \\
\hline Atypichthys strigatus & 2 & 5 & & 9 & & & 1 & & & 1 & \\
\hline Microcanthus strigatus & 5 & 6 & & 4 & & & 3 & 6 & & 1 & \\
\hline Monocanthidae & & & & & & & & & & & \\
\hline Acanthaluteres vittiger & & & & 1 & 3 & & & 1 & & 2 & 1 \\
\hline Brachaluteres jacksonianus & & 2 & & 2 & & & & & & & \\
\hline Meuschenia trachylepis & & & & & 2 & & & & & & \\
\hline Monocanthus chinensis & 1 & 2 & & 4 & 2 & & 1 & & & 7 & 2 \\
\hline Eubalichthys mosaicus & & & & 2 & & & 1 & & & & \\
\hline Meuschenia freycineti & & & & 3 & 3 & & & & & & \\
\hline Unidentified juvenile & & & & 2 & & & 2 & & & & \\
\hline Monodactylidae & & & & & & & & & & & \\
\hline Monodactylus argenteus & 1 & 2 & & 3 & & & 3 & 2 & & 2 & \\
\hline
\end{tabular}




\begin{tabular}{|c|c|c|c|c|c|c|c|c|c|c|}
\hline \multirow[t]{3}{*}{ Family/Species } & \multicolumn{5}{|c|}{ Sydney Harbour } & \multicolumn{5}{|c|}{ Pittwater } \\
\hline & \multicolumn{3}{|c|}{ Surface } & \multicolumn{2}{|c|}{ Bottom } & \multicolumn{3}{|c|}{ Surface } & \multicolumn{2}{|c|}{ Bottom } \\
\hline & Po & $\mathbf{P i}$ & Ow & $\mathbf{P i}$ & Ow & Po & $\mathbf{P i}$ & Ow & $\mathbf{P i}$ & Ow \\
\hline \multicolumn{11}{|l|}{ Mugilidae } \\
\hline Mugil cephalus & & & & & & & & 1 & & \\
\hline \multicolumn{11}{|l|}{ Mullidae } \\
\hline Upeneichthys lineatus & & & & 1 & & & & & & \\
\hline Upeneus tragula & & & & 5 & 4 & & & & & \\
\hline Parupeneus signatus & & 1 & & 1 & & & & & & \\
\hline \multicolumn{11}{|l|}{ Plesiopidae } \\
\hline Trachinops taeniatus & 19 & 16 & & 33 & & & 0 & & 7 & \\
\hline \multicolumn{11}{|l|}{ Pomacentridae } \\
\hline Abudefduf sexfasciatus & & 2 & & & & & & & & \\
\hline Chromis nitida & & 1 & & 2 & & & & & & \\
\hline Mecaenichthys immaculatus & 3 & 4 & & 7 & & & & & & \\
\hline Parma microlepis & & 1 & & 1 & & & & & & \\
\hline \multicolumn{11}{|l|}{ Pomatomidae } \\
\hline \multicolumn{11}{|l|}{ Pomatomus saltatrix } \\
\hline \multicolumn{11}{|l|}{ Scorpaenidae } \\
\hline \multicolumn{11}{|l|}{ Centropogon australis } \\
\hline \multicolumn{11}{|l|}{ Scorpididae } \\
\hline Scorpis lineolate & 3 & & & 4 & D & & & & & \\
\hline \multicolumn{11}{|l|}{ Serranidae } \\
\hline \multicolumn{11}{|l|}{ Diploprion bifasciatum } \\
\hline \multicolumn{11}{|l|}{ Sparidae } \\
\hline Acanthopagrus australis & 4 & 11 & & 26 & 30 & & 9 & 2 & 26 & 35 \\
\hline Chrysophrys auratus & & & & 7 & 7 & & & & 2 & 1 \\
\hline \multicolumn{11}{|l|}{ Syngnathidae } \\
\hline \multicolumn{11}{|l|}{ Hippocampus whitei } \\
\hline Festucalex cinctus & & & & 1 & 1 & & & 1 & & \\
\hline \multicolumn{11}{|l|}{ Tetraodontidae } \\
\hline \multicolumn{11}{|l|}{ Arothron hispidus } \\
\hline \multicolumn{11}{|l|}{ Tripterygiidae } \\
\hline Enneapterygius rufopileus & & 5 & & 2 & & & 4 & 1 & 6 & \\
\hline \multicolumn{11}{|l|}{ Urolophidae } \\
\hline Trygonoptera testacea & & & & 1 & 6 & & & & & \\
\hline Unidentified juvenile fish & & 7 & 2 & 5 & 2 & & 9 & 8 & 4 & \\
\hline
\end{tabular}


Table 3 Species that each contributed $\geq 10 \%$ to measures of dissimilarity between habitats at (i) the surface; pontoons, pilings and open water and (ii) at the bottom; pilings and open water.

Data are the number of times (out of three times of sampling) a species contributed $>10 \%$ to measures of dissimilarity. The range of values of dissimilarity are in brackets.

565

\begin{tabular}{lllll}
\hline & & (i) Surface & & (ii) Bottom \\
\hline Species & Pon vs Pil & Pon vs Ow & Pil vs Ow & Pil vs Ow \\
& \multicolumn{1}{c}{$\%$} & \multicolumn{1}{c}{$\%$} & $\%$ & $\%$ \\
\hline Trachinops taeniatus & $3(28-49)$ & $3(15-38)$ & $3(12-23)$ & $3(10-23)$ \\
Girella tricuspidata & $3(10-21)$ & $2(6-22)$ & $2(3-21)$ & $0(1-5)$ \\
Parablennius intermedius & $1(0-10)$ & $0(0-8)$ & $1(0-10)$ & - \\
Microcanthus strigatus & $1(0-14)$ & $1(0-12)$ & $0(0-4)$ & - \\
Atherinidae & - & $1(0-16)$ & $1(0-18)$ & $0(0-2)$ \\
Acanthopagrus australis & $0(1-9)$ & $2(3-19)$ & $2(6-14)$ & $3(15-33)$ \\
Gerres subfasciatus & $0(5-6)$ & $1(0-19)$ & $2(0-27)$ & $1(0-14)$ \\
Trachurus novaezelandiae & - & $0(0-2)$ & $0(0-3)$ & $2(5-20)$ \\
\hline
\end{tabular}

